\section{Effect of temperature on morphogenetic oscillations in Dictyostelium discoideum}

WHEN their food supply is exhausted, single amoebae of the cellular slime mould Dictyostelium discoideum aggregate'. On a two-dimensional substrate such as agar, this aggregation is the result of a succession of periodic coordinated movement steps directed towards a group of amoebae-the "centre", which may in fact lie anywhere in the field of cells. Recent theoretical", and experimental ${ }^{+-i}$ work suggests that this process can be explained as follows. (1) The centre produces and releases cyclic AMP (the signal) in an oscillatory manner, and (2) other cells in the field respond chemotactically by moving up cyclic AMP gradients and relay the signal progressively outwards. By means of time-lapse cinematography we have looked at the oscillation frequency $v$ during the aggregation of small drops (about 1,000 cells in a drop of diameter $1 \mathrm{~mm}$ ) of $D$. discoideum cells (strain $\mathrm{NC}-4 \mathrm{H}$ ) aggregating on hydrophobic agar ${ }^{8}$ at various temperatures, and have found that the oscillation frequency increases with temperature (Fig. 1).

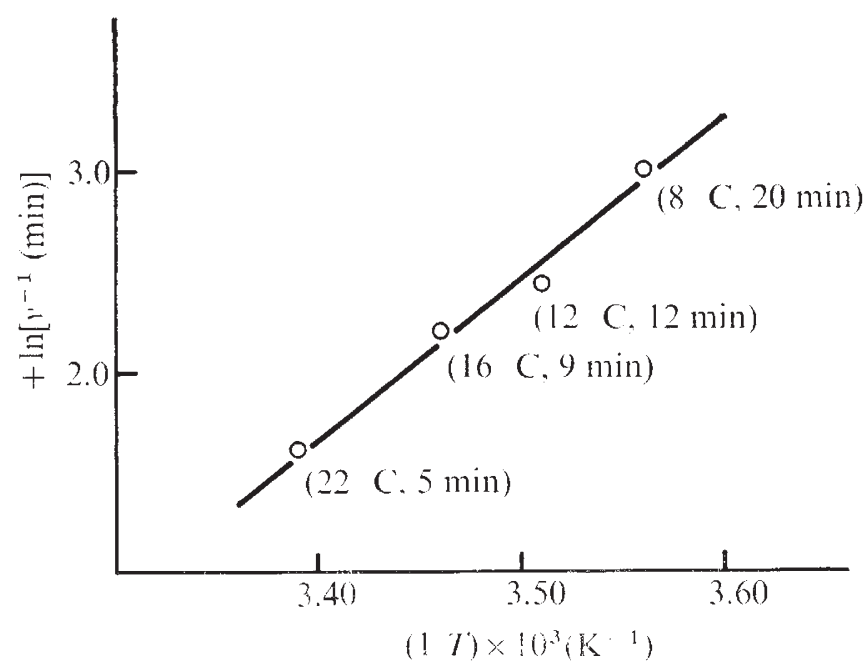

Fig. $1 T$ is the absolute temperature and $v$ the frequency of oscillation. Experimental points are fitted to the curve ln $\left(v^{-1}\right)=\ln \left(v_{0}{ }^{-1}\right)+(\triangle E / R) T^{-1}$, with $R$ equal to the gas constant. Figures in parentheses indicate the temperature $\left({ }^{\circ} \mathrm{C}\right)$ and period of oscillation. The amocbae were deposited in a drop of Bonner's salt solution ${ }^{11}$ on agar, and the agar plate was kept in the temperature-controlled room for $2-3 \mathrm{~h}$ before aggregation began. Temperature varied within $+0.5^{\circ} \mathrm{C}$ of the recorded means. Periods were recorded as differences in times of initiation of wave propagation at the centre, each such initiation having the appearance of a quick contraction. Mean frequencies were estimated from two experiments at each temperature with about 15 oscillations recorded during each aggregation. A sample run of periods, recorded at $12^{\circ} \mathrm{C}$, reads $13,12,12,13,13,12,12,12,11,12 \mathrm{~min}$. The aggregates were concentric, that is, morphologically similar in all experiments.

These amocbac aggregate and form viable spores (as tested at $\left.22{ }^{\circ} \mathrm{C}\right)$ down to $8{ }^{\circ} \mathrm{C}$. The Arrhenius plot $\left(\ln \nu^{-1}\right.$ against $\ln T^{-1}$ ) is linear, corresponding to a frequency factor $\nu_{1}=2 \times 10^{9} \mathrm{~s}^{-1}$ and an activation energy $\Delta E=15.8$ kcalorie $\mathrm{mol}^{-1} . \Delta E$ can be interpreted as the activation energy of a (hypothetical) rate-limiting step in the overall scheme for the biochemical oscillation. It is noteworthy that this value of $\Delta E$ is in the range of activation energies for nontransport enzyme-catalysed reactions", whereas those for known specific transport processes are much smaller ${ }^{10}$. In parallel with the increase in oscillation frequency, there is also an increase in the mean speed of amoeboid move- ment (not shown). Thus, other factors being the same, the number of pulses needed for a field of cells to aggregate ought to be only weakly temperature dependent. In fact, if we consider just those cases (four in all) where oscillations could still be observed till late in aggregation, this number was 20 at $12{ }^{\circ} \mathrm{C}, 19$ at $16^{\circ} \mathrm{C}$ and 17 at $22^{\circ} \mathrm{C}$, Rigorous substantiation of this last result would suggest that there is an underlying oscillator controlling movement, possibly coupled to the one involved in signal generation.

Biozentrum der Universität,

VIDYANAND NANJUNDIAH

4056 Basel, Switzerland

Hubrecht Laboratory,

KOKI HARA

Uppsalalaan 8

Utrecht

Zoölogisch Laboratorium,

Rijksuniversiteit te Leiden,

The Netherlands

Received December 4, 1975; accepted February 20, 1976.

${ }^{1}$ Bonner, J. T., The Cellular Slime Molds (Princeton University Press, New Jersey, 1967).

Goldbeter, A.. Nature, 253 (5492), 540-542 (1975).

3 Nanjundiah, V., J. theor. Biol., 56, 275-282 (1976).

${ }_{4}^{4}$ Gerisch, G., and Wick, U., Biochem. biophys. Res. Commun., 65(1), 364-370, (1975)

Roos, W., Nanjundiah, V., Malchow, D., and Gerisch, G., FEBS Lett., 53(2), $139-142$ (1975)

6 Shaffer, B. M., Nature, 255, 549-552 (1975).

Mato, J. M., Losada, A.. Nanjundiah, V., and Konijn, Th. M., Proc. natn. Acid. Sci. U.S.A. 72, $4991-4993$ (1975).

8 Konijn, Th. M., and Raper, K. B., Devl Biol., 3, 725-756 (1961).

Dawes, E. A., in Comprehensive Biochemistry, 12 (edit. by Florkin, M., and

Stotz, E. H.) (Elsevier, New York, 1964).
10 Stein, W. D., The Movement of Molecules Across Cell Membranes (Academic, New York, 1967).

11 Bonner, J. T., J. exp. Zool., 106, 1-26 (1947).

\section{External cyclic AMP-dependent protein kinase activity in rat $\mathrm{C}-6$ glioma cells}

IN certain eukaryotic cells $\beta$-agonistic catecholamines bind to membrane-associated hormone receptors, and stimulate the intracellular synthesis of cyclic AMP by activation of the adenylate cyclase'. In C-6 rat glioma cclls stimulated with noradrenaline this increase of cyclic AMP leads to, or is correlated with, a morphological change in the cells ${ }^{2}$. When the intracellular cyclic AMP concentration has reached a maximum, it returns to basal values ${ }^{2}$ due to an energydependent excretion of cyclic AMP from the cell into the external medium $m^{3,4}$, similar to that found in several mammalian systems ${ }^{5-7}$. It is possible that the excreted cyclic AMP interacts either with an external, glial-membrane bound cyclic AMP receptor or with the surface of the surrounding cells, for example neurones. We report here that intact, cultured glial cells seem to have a cyclic AMPdependent protein kinase on their external surface which transfers $\gamma$-phosphate of ATP to an external acceptor protein (histone). This protein kinase activity is stimulated indirectly by the addition of noradrenaline to the cells. The physiological significance of this process is unknown.

We first tested the effect of extracellular cyclic AMP on the ability of a protein kinase activity of intact C-6 cells to phosphorylate an exogenous substrate. Figure 1 shows the phosphorylation by $\mathrm{C}-6$ cells of added external histones as a response to incubation in the presence of $5 \times 10^{-6} \mathrm{M}$ cyclic AMP. These data suggest that actively growing glial cells have a cyclic AMP-dependent protein kinase, probably on the external cell surface, which can be stimulated from the outside of the membrane. The same experiment showed that a small fraction of ${ }^{32} \mathrm{P}$ radioactivity remained with the cells and that there was no significant difference between stimulated and unstimulated cells with respect to this accumulation (data not shown).

There are two possible objections to the experiment 